\title{
Summer dynamics of the coastal planktonic food web in the northern Baltic Sea
}

\author{
A. Uitto ${ }^{1, *}$, A.-S. Heiskanen ${ }^{2}$, R. Lignell ${ }^{3}$, R. Autio ${ }^{1}$, R. Pajuniemi ${ }^{1}$ \\ ${ }^{1}$ Tvärminne Zoological Station, University of Helsinki, FIN-10900 Hanko, Finland \\ ${ }^{2}$ Finnish Environment Institute, PO Box 140, FIN-00251 Helsinki, Finland \\ ${ }^{3}$ Department of Limnology and Environmental Protection, PO Box 27, FIN-00014 University of Helsinki, Finland
}

\begin{abstract}
Summer carbon flow in the pelagic food web was studied within the coastal region of the northern Baltic Sea. Heterotrophic nanoflagellates (HNAN) transferred carbon from picoplankton to ciliates, while ciliates linked nano- and metazooplankton. Hydrodynamic conditions affected the planktonic community, and 3 different periods characterised by distinct community structure and carbon flow dynamics could be distinguished. All trophic groups were largely omnivorous, but the role of herbivory and feeding on heterotrophs varied during summer In early June, an upwelling mixed the upper water layer. The water column was rich in detritus, remnants from the preceding spring phytoplankton bloom. Phytoplankton was dominated by $>10 \mu \mathrm{m}$ phytoplankton, that was grazed by metazooplankton and heterotrophic dınoflagellates. At the same time HNAN were largely bacteriovorous, thus the microbial food web (MFW) could transfer bacterial carbon to ciliates and metazooplankton. In July during strong thermal stratification the biomass of $<10 \mu$ m phytoplankton increased, and protists became the most important herbivores. In addition to grazing, metazooplankton gained nanophytoplankton carbon through the MFW by feeding on ciliates. Strong horizontal currents due to upwelling destroyed the stable mid-summer communty in late July. Primary production, the biomass of phytoplankton and metazooplankton declined abruptly, whereas the detritus pool increased agaın. Because all trophic groups fed largely on heterotrophs, the efficiency of the MFW in transferring bacterial carbon to metazooplankton was estimated to be at its highest. When integrated throughout the summer, primary production was $20.5 \mathrm{~g} \mathrm{~m}^{-2}$, from which sedimentation, herbivory by protists and herbivory by metazooplankton accounted for 27,40 and $26 \%$, respectively. Bacterial production was $8 \mathrm{~g} \mathrm{~m}^{-2}$, from which HNAN and ciliates grazed approximately $60 \%$. Excepting the sedimentation in early June, carbon was mostly recycled within the planktonic community during the summer
\end{abstract}

KEY WORDS: Primary production Bacterial production Sedimentation Grazing food chain Microbial food web. Trophic interactions

\section{INTRODUCTION}

Information regarding the basic trophic structure and functioning of the pelagial food web has advanced considerably, enabling the construction of schematic representations of the systems (Taylor \& Joint 1990 , Legendre \& Rassoulzadegan 1995). Energy supplied to higher trophic levels is transferred through 2 main pathways: the herbivorous grazing food chain from larger phytoplankton to metazooplankton, and the microbial food web, in which mostly picoplanktonic

·E-mäil: anna uitto@helsinki.fj carbon is transferred to protists and only a minor part of the carbon is available to higher trophic levels (Ducklow et al. 1986, Hagström et al. 1988, Wikner et al. 1990). However, the ability of many metazoan and protozoan species, traditionally grouped into separate trophic levels, to use particles from a very wide size range means that the models describing carbon pathways have become more complicated (Turner \& Roff 1993) Copepods, cladocerans and rotifers are known to be largely omnivorous (Stoecker \& Egloff 1987, Wiadnyana \& Rassoulzadegan 1989, Stoecker \& Capuzzo 1990). Thus, when metazooplankton species feed on protists of a wide size range, which in turn are known efficiently to consume pico- and nanoplankton, the 
energy transfer from the microbial loop (ML; including bacteria and protists) and from the microbial food web (MFW; including also autotrophic pico- and nanoplankton) (sensu Rassoulzadegan 1993) to higher trophic levels can be greater than previously assumed. However, even the simplest empirical quantification of ecological energetics requires a wide range of measurements on different possible interactions between the main species groups of different trophic status (Pomeroy \& Wiebe 1988).

Seasonal dynamics of the pelagic community from primary producers to metazooplankton has been intensively studied in the field, as well as in mesocosm and laboratory experiments, in the Tvärminne sea area of the coastal northern Baltic Sea. In spring, phytoplankton is composed mostly of large diatoms that are sedimented (Lignell et al. 1993). During summer autotrophic and heterotrophic pico- and nanoplankton become dominant, while later in summer, the biomass of filamentous bluegreen algae increases (Niemi 1973, 1975, Forsskåhl \& Sundberg 1981. Huttunen \& Kuparinen 1986, Kuosa 1991, Kuuppo-Leinikki 1993, Kononen et al. 1996), and sedimentary losses gradually decrease (Heiskanen \& Leppänen 1995). The summer net primary production is mainly limited by nitrogen and phosphorus (Tamminen et al. 1985), but productivity occasionally increases in the euphotic zone when wind-induced vertical mixing brings nutrient-rich water from the deeper water mass to the upper water layer (Kononen et al. 1996). Thermal stratification gives rise to the development of the summer metazooplankton community, dominated by copepods, cladocerans and rotifers (Viitasalo et al. 1995). Heterotrophic nanoflagellates (HNAN) are the main consumers of bacteria (Autio et al. 1988, Kuosa \& Kivi 1989, Kuuppo-Leinikki 1990) and autotrophic picoplankton (Kuosa 1991). Nanoplankton is largely grazed by microprotists $(>20 \mu \mathrm{m})$ dominated by ciliates and heterotrophic dinoflagellates (Kivi \& Setälä 1995), and by metazooplankton dominated by calanoid copepods, cladocerans and rotatorians (Uitto 1996a). Bacterial production is limited by dissolved organic carbon and inorganic nutrients (Lignell et al. 1992, Kuparinen \& Heinänen 1993)

In the present study, the structure and dynamics of the pelagic community in the euphotic zone were evaluated, combining data from different pelagic compartments mentioned above. All measurements were carried out in the Tvärminne sea area or a nearby archipelago area, and most of the studies were carried out during the summer of 1988 . The study aims to empirically quantify the main carbon flow from primary and bacterial production to metazooplankton during summer, to assess the transfer efficiency of different trophic groups, and to construct a carbon budget for the study area.

\section{MATERIAL AND METHODS}

Sampling. The study area is located in the coastal area of SW Finland $\left(59^{\circ} 47^{\prime} \mathrm{N}, 23^{\circ} 30^{\prime} \mathrm{E}\right)$, where water depth is around $46 \mathrm{~m}$. Salinity varies from 6 to 8 psu and the water column lacks a permanent halocline. The thermocline is usually located at 10 to $30 \mathrm{~m}$ depth during the summer, but is interrupted by vertical mixing of water masses caused by irregular upwellings and downwellings. A more detailed description of the hydrography of the sea area during 1988 is presented by Haapala (1994).

Water samples were taken weekly between 2 and 16 June, and thereafter every other week until 24 August 1988. Temperature was measured from 0, 2.5, $5,10,15,20,30$ and $40 \mathrm{~m}$ depth using a water sampler equipped with a thermometer. At the same time, the vertical distribution of salinity (Autosal Laboratory salinometer) was measured. Phytoplankton samples from $0,2.5,5,10$ and $15 \mathrm{~m}$ depth were pooled before phytoplankton enumeration. Samples for zooplankton enumeration were taken from $0,5,10$ and $15 \mathrm{~m}$ depth. Phytoplankton and microprotists samples were preserved with acid Lugol's iodine solution (ca $0.5 \%$ final concentration). The metazooplankton samples were filtered through a $40 \mu \mathrm{m}$ mesh net, and the retained material was rinsed to $1 \mathrm{l}$ bottles and preserved with $4 \%$ buffered formalin. Sampling and staining of heterotrophic nanoflagellates are presented in Kuosa (1991). The bacteria samples were collected from 0. 2.5, 5, and $10 \mathrm{~m}$ depth

Microscopy and biomass determinations. The samples of phytoplankton, metazooplankton and microprotists were prepared for counting according to Utermöhl (1958) and enumerated using an inverted microscope. At least 50 or 100 units (cells, chains or colonies) of the most abundant $>2 \mu \mathrm{m}$ phytoplankton species were counted. The phytoplankton plasma volume and carbon-biomass values were calculated according to Strathmann (1967) and Sicko-Goard et al. (1977), but modified as suggested by the Baltic Marine Biologists (Edler 1979) and Kononen et al. (1984). The genus Protoperidinium (Jacobson \& Anderson 1986) and the species Ebria tripartita Lemmermann were grouped as heterotrophs. When possible, at least 50 counting units were enumerated for each taxon of metazooplankton and microprotists. The species-specific biovolumes were converted to carbon equivalents using carbon contents of $0.11 \mathrm{pg} \mathrm{C} \mu \mathrm{m}^{-3}$ for protozoan microplankton (Edler 1979), and $0.05 \mathrm{pg} \mathrm{C} \mu \mathrm{m}^{-3}$ for metazooplankton (Mullin 1969)

Bacterial cell numbers were measured according to Hobbie et al. (1977). Water samples of $10 \mathrm{ml}$ were preserved with particle-free formalin $37 \%$ formaldehyde, $2 \%$ final concentration) and stored in a refrigerator. In 
a few weeks' time subsamples of $1 \mathrm{ml}$ were stained with acridine orange and collected on black $0.2 \mu \mathrm{m}$ pore-sized polycarbonate filters. The filters were examined with an epifluorescence microscope. Bacterial biomass was estimated using a mean cell volume of $0.045 \mu^{3}$ and a mean carbon content of $0.27 \mathrm{pg} \mathrm{C}$ $\mu \mathrm{m}^{-3}$ (Kuparinen 1988), both measurements made in the Tvärminne sea area. The bacterial biovolume used is within the range of 16 to $46 \mathrm{pg} \mathrm{C} \mu \mathrm{m}^{-3}$, measured by Heinänen (1992) for the open sea area of the Gulf of Finland during late summer in 1988. The biomass of picoplanktonic cyanobacteria was obtained from the measurements by Kuosa (1991).

Primary and bacterial productivity. The incubation depths for the in situ primary productivity measurements were $0.2,1,2.5,5,7$ and $9 \mathrm{~m}$, approximately covering the entire euphotic layer. Primary productivity was measured by the ${ }^{14} \mathrm{C}$ method (Steemann Nielsen 1952). Duplicate light bottles were used at each incubation depth and duplicate dark bottles at 2.5 and $7 \mathrm{~m}$. Light attenuation (Mavolux light meter, Germany) in the water column was measured. The incubations were started between 10:00 and 11:00 h and lasted for 5 to $6 \mathrm{~h}$. A short incubation time was used to avoid the bias caused by intensified herbivorous feeding and the subsequent respiratory losses of algal ${ }^{14} \mathrm{C}$; the primary production values from short incubations were transformed to daily values by correcting with the ratio of the corresponding cumulative irradiation values (Kipp \& Zonen light meter, The Netherlands). Primary productivity (particulate plus dissolved organic ${ }^{14} \mathrm{C}$ ) was measured by allowing an acidified $4 \mathrm{ml}$ subsample to stand in uncapped $20 \mathrm{ml}$ glass scintillation vials for 24 h (ventilation cupboard, no bubbling) before the scintillation cocktail (Lumac) was added (Niemi et al. 1983). Radioactivity was measured with a LKB Rackbeta 1215 liquid scintillation counter. In ${ }^{14} \mathrm{C}$ primary productivity calculations, the dark values were subtracted from the corresponding light values. Dissolved inorganic carbon was measured with an infra-red carbon detector (Elektro-Dynamo carbon analyser, Finland). Due to limited irradiation data, variations in the depth of saturating light levels during the day could not be taken into account. Simple calculations (assuming no light saturation of photosynthesis during the light period not covered by incubations) suggested, however, that our approach led to only a small (usually $<10 \%$ ) underestimate of the daily productivity values.

Bacterial production was estimated using the thymidine incorporation technique of Fuhrman \& Azam (1980, 1982), with slight modifications. Duplicate $20 \mathrm{ml}$ samples and a formalin-killed adsorption control were incubated with [methyl- ${ }^{3} \mathrm{H}$ ]-thymidine ( $10 \mathrm{nM}$ final concentration, 40 to $42 \mathrm{Ci} \mathrm{mmol}^{-1}$; Amersham International) for $1 \mathrm{~h}$. The incubations were terminated with formalin $37 \%$ formaldehyde, $0.5 \%$ final concentration). The samples were stored in a refrigerator until macromolecule extraction, which was always done within $24 \mathrm{~h}$. The samples were chilled below $3^{\circ} \mathrm{C}$ and extracted with TCA (5\% final concentration). The macromolecules were collected on $0.2 \mu \mathrm{m}$ pore-sized cellulose nitrate filters (Sartorius). The filters were placed into scintillation vials and soaked with PCS (Amersham) scintillation cocktail. In order to let the filters dissolve, counting was postponed for at least $12 \mathrm{~h}$. The incorporated radioactive thymidine was assayed with a liquid scintillation counter. Daily bacterial carbon production was calculated using the thymidine conversion factor of $1.1 \times$ $10^{18}$ cells $\mathrm{mol}^{-1}$ thymidine incorporated (Riemann et al. 1987). The growth yield of bacteria was $40 \%$ [measured with ${ }^{14} \mathrm{C}$-labelled DOC (dissolved organic carbon, released from natural phytoplankton communities in the study area; R. Lignell pers. comm.].

Sedimentation. Settled material was collected at 5 to $9 \mathrm{~d}$ intervals from 2 to 15 June and thereafter at $2 \mathrm{wk}$ intervals until 25 August by using cylindrical sediment traps (height:diameter $=10$ ) moored at 15 and $30 \mathrm{~m}$ depth. Sediment trap samples were preserved with $50 \mathrm{ml}$ of non-buffered, concentrated formaldehyde during deployment. Samples for particulate organic carbon (POC) were filtered in triplicate on acidwashed and precombusted $\left(4 \mathrm{~h}\right.$ at $450^{\circ} \mathrm{C}$ ) glass-fiber filters (Whatman GF/F) and analysed with a Heraeus CHN analyser. Metazooplankton swimmers were removed from the filters under a stereomicroscope. A detailed description of sediment trap sampling, analysis, and corrections of the phytoflagellate migration contamination and resuspension are presented in Heiskanen (1995) and Heiskanen \& Leppänen (1995).

Ingestion by heterotrophs. Grazing by mesozooplankton and metazoan microplankton was measured on respective sampling days by Uitto (1996a) in the study area, using a ${ }^{14} \mathrm{C}$-tracer feeding technique and 2 cultures of autotrophic nanoflagellates. The biomass specific clearance rates of 0.7 to $3.9 \mathrm{ml} \mathrm{\mu g}^{-1} \mathrm{C} \mathrm{d}^{-1}$ on

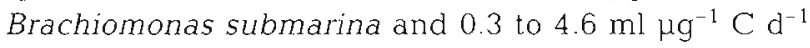
on Pavlova lutheri, were used to estimate the grazing of mesozooplankton on $>10 \mu \mathrm{m}$ and 2 to $10 \mu \mathrm{m}$ sized natural phytoplankton, respectively. For metazoan microplankton the corresponding values were 1.1 to

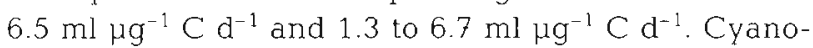
bacteria were not included in the larger phytoplankton group, because they are not grazed by metazooplankton in the study area (Sellner et al. 1994). All other species, dominated by nanoflagellates, were assumed to be palatable to zooplankton. Mesozooplankton and metazoan microplankton grazing on HNAN was calculated according to measurements made in a mesocosm experiment in the nearby archipelago area during the same summer (Uitto 1996b) using the average daily 
biomass specific clearance rate of $1.02 \mathrm{ml} \mathrm{\mu g}^{-1} \mathrm{C}$ for mesozooplankton and $3.3 \mathrm{ml} \mathrm{\mu g}^{-1} \mathrm{C}$ for metazoan. microplankton. Ingestion of ciliates, Protoperidinium. sp. and Mesodinium rubrum by adult copepods were estimated using the clearance rates of 0.4 to $1.6 \mathrm{ml}$ ind. ${ }^{-1} \mathrm{~h}^{-1}$. These rates had been measured for Acartia spp. found in the same study area, ingesting microplankton at a temperature of 13 to $18^{\circ} \mathrm{C}$ (Kivi 1996). The clearance rates of 3 smaller size categories of different developmental copepod stages were estimated by applying the allometric equation of Moloney \& Field (1989).

Ciliate grazing on 2 to $10 \mu \mathrm{m}$ phytoplankton and on HNAN was estimated using the clearance rate measurements of Kivi \& Setälä (1995) made on natural communities in the same study area during the summers of 1987 and 1989. In their study, clearance rates of several oligotrich ciliate species were measured using starch particles as a food tracer. The size-specific clearance rate of each species of protozoan microplankton was estimated with the equation. $y=2.67+47.57 x$, where $y$ stands for clearance rate $\left(\mu \mathrm{l} \mathrm{cell}^{-1} \mathrm{~h}^{-1}\right)$, and $x$ for cell biovolume. Ciliates were assumed to graze only on phytoplankton $<10 \mu \mathrm{m}$, as the optimal food size of ciliates in the study area is around $5 \mu \mathrm{m}$ (Kivi \& Setälä 1995). Ciliate grazing on bacteria and picocyanobacteria was estimated on the basis of the measurements of Kuuppo-Leinikki (1990) during the enclosure experiment conducted in the nearby archipelago area in 1988; the mean daily biomass-specific clearance rate of

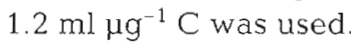

The carbon requirement of Ebria tripartita and Protoperidinium spp. was estimated according to the highest growth rate $(k)$ found between 2 and 9 June: $k=$ $\left(\ln C_{t}-\ln C_{0}\right) / t_{1}$ where $t$ is the sampling interval $(7 \mathrm{~d})$ and $C_{t}$ and $C_{0}$ are the carbon biomass values on the 2 consecutive samplings. The daily production $(P)$ was thus estimated using the formula: $P=k \times B$. The carbon requirement of these groups was estimated by assuming a growth yield of $40 \%$ (Fenchel 1982). Because these taxa are known to feed extracellularly on large diatoms (Jacobson \& Anderson 1986), their feeding was assumed to be restricted to phytoplankton $>10 \mu \mathrm{m}$.

Biomass, grazing on picoplanktonic cyanobacteria and production of HNAN were calculated using the abundance, grazing and daily growth rate measurements made by Kuosa (1991) in the same study area in 1988. Daily grazing by HNAN on bacteria was estimated from the grazing and growth measurements made by Kuosa (1991). Total carbon requirement of HNAN was calculated from production $(P)$ assuming the growth yield of $40 \%$ (Fenchel 1982), from which the measured proportion of HNAN grazing on picocyanobacteria was subtracted to estimate the HNAN ingestion of bacteria.
Total particulate and dissolved detrital carbon. The proportion of POC in the form of detrital particulate carbon (DPC) was calculated by subtracting the amount of total autotroph and heterotroph biomass from POC. Non-ingested particulate carbon remained from the estimated daily production of different trophic groups and faecal pellets of metazooplankton were assumed to be usable detrital carbon (UDC) for bacterial production. DOC released directly to the water was assumed to come from phytoplankton exudation (about $10 \%$ of primary production in the study area; Lignell 1990) and from metazooplankton sloppy feeding $(10 \%$ of total feeding; Lampert 1978). The production of faecal pellets was estimated by assuming an assimilation efficiency of $60 \%$ for metazooplankton (Laws et al. 1988), thus $40 \%$ of total ingested carbon would be transformed to faecal pellets. Other sources for UDC were estimated to originate from primary and secondary production of different trophic groups that was not consumed by heterotrophs.

Calculating food web dynamics. All biomass concentrations and rate measurements were integrated between 0 and $10 \mathrm{~m}$. Food web efficiency was calculated assuming that the ration of different carbon sources in the secondary production of a trophic group will remain the same as in that ingested by the same group. Autotrophs were assigned to 3 size-classes; $<2 \mu \mathrm{m}, 2$ to $10 \mu \mathrm{m}$, and $>10 \mu \mathrm{m}$, an autotrophic ciliate Mesodinium rubrum. Heterotrophs were divided into bacteria, HNAN, ciliates, the heterotrophic dinoflagellate Protoperidinium spp., the ebrian Ebria tripartita, $<140 \mu \mathrm{m}$ metazoan microplankton and $>140 \mu \mathrm{m}$ mesozooplankton (cf. Sieburth et al. 1978). Pico-, nano-, micro- and metazooplankton were assumed to form 4 functional groups within the food web, thus the food web structure was composed of 1-step food chains (direct ingestion of autotrophs and bacteria) and 2- to 3 -step food chains (ingestion of heterotrophs by different trophic groups).

$$
\begin{aligned}
& I \cdot 2=\left(I_{X_{1}} / T I_{X_{1}}\right) I_{X_{i+1}} \\
& I \cdot 3=\left(I_{X_{1}} / T I_{X_{1}}\right)\left(I_{X_{1+1}} / T I_{X_{1+1}}\right) I_{X_{1+2}} .
\end{aligned}
$$

where $I^{2} 2$ is the daily amount of carbon $\left(\mathrm{mg} \mathrm{C} \mathrm{m}{ }^{-2}\right.$ ) transferred through the 2 food steps to be ingested by microprotists or metazooplankton, $I \cdot 3$ is the corresponding carbon transferred through the 3 food steps to be ingested by metazooplankton, $I$ is the ingestion of a lower trophic group by a 1-step higher trophic group (i.e. the ingestion of bacteria and picocyanobacteria by HNAN or microprotists; ingestion of HNAN and 2 to $10 \mu \mathrm{m}$ phytoplankton by microprotists or metazooplankton; ingestion of microprotists and $>10 \mu \mathrm{m}$ phytoplankton by metazooplankton), $T$ is the total ingestion by a 1-step higher trophic group, and $X_{11} X_{1+1}$ and $X_{1+2}$ are 3 different trophic groups corre- 
sponding to nanoheterotrophs, microprotists (ciliates and Protoperidinium spp.) and metazooplankton (mesozooplankton and metazoan microplankton).

\section{RESULTS}

\section{Hydrography}

Three different periods of hydrodynamic events occurred in the study area. In the beginning of June, a strong upwelling mixed the water column (cf. Lignell et al. 1993, Haapala 1994), after which thermal stratification began to develop (Fig. 1A). The second period was characterised by thermal stratification which prevailed from late June until the end of July. The third period began in late July, when the wind induced strong surface currents directed towards the coast, causing a downwelling in the study area (Haapala 1994). This event was concurrent with a decrease in surface layer temperature and salinity (Fig. 1A, B). The downwelling was soon followed by an upwelling and simultaneous strong off-shore current of the surface layer, which was followed by a weakening of thermal stratification and a further fall in temperature and increase of salinity in August.

\section{Succession and biomass development of different trophic groups}

Phytoplankton biomass varied from 375 to $1200 \mathrm{mg}$ $\mathrm{C} \mathrm{m}^{-2}$, being largest in June (Fig. $2 \mathrm{~A}$ ). In early June, it was composed mostly of $>10 \mu \mathrm{m}$ phytoplankton, dominated by the diatoms Skeletonema costatum (Greville) Cleve and Chaetoceros wighamii Brightwell; the dinoflagellates Peridiniella catenata (Levander) Balech, Dinophysis acuminata Claparède \& Lachmann; Gymnodinium sp. and and by an euglenoid flagellate Eutreptiella sp. After mid-June the remains of the vernal phytoplankton community (i.e. $S$ costatum and $P$. catenata) disappeared. The warm and relatively stable period from late June until mid-July was characterised by the dominance of 2 to $10 \mu \mathrm{m}$ nanoflagellates, especially Chrysochromulina spp., Cryptomonas spp. and Pedinella spp. (Fig. 2A). The biomass of picoplanktonic cyanobacteria, mostly Synechococcus, also increased (Kuosa 1991). Blue-green algae were dominated by Aphanizomenon cf. flos-aquae (L.) Ralfs during the summer.

Biomass of metazooplankton was $165 \mathrm{mg} \mathrm{C} \mathrm{m}^{-2}$ on 2 June, but increased within 2 wk to the maximum $1110 \mathrm{mg} \mathrm{C} \mathrm{m}{ }^{-2}$, due to the growth of Synchaeta spp. and meroplanktonic bivalvia larvae (Fig. 2B). Eurytemora affinis (Poppe) CI-CVI became dominant
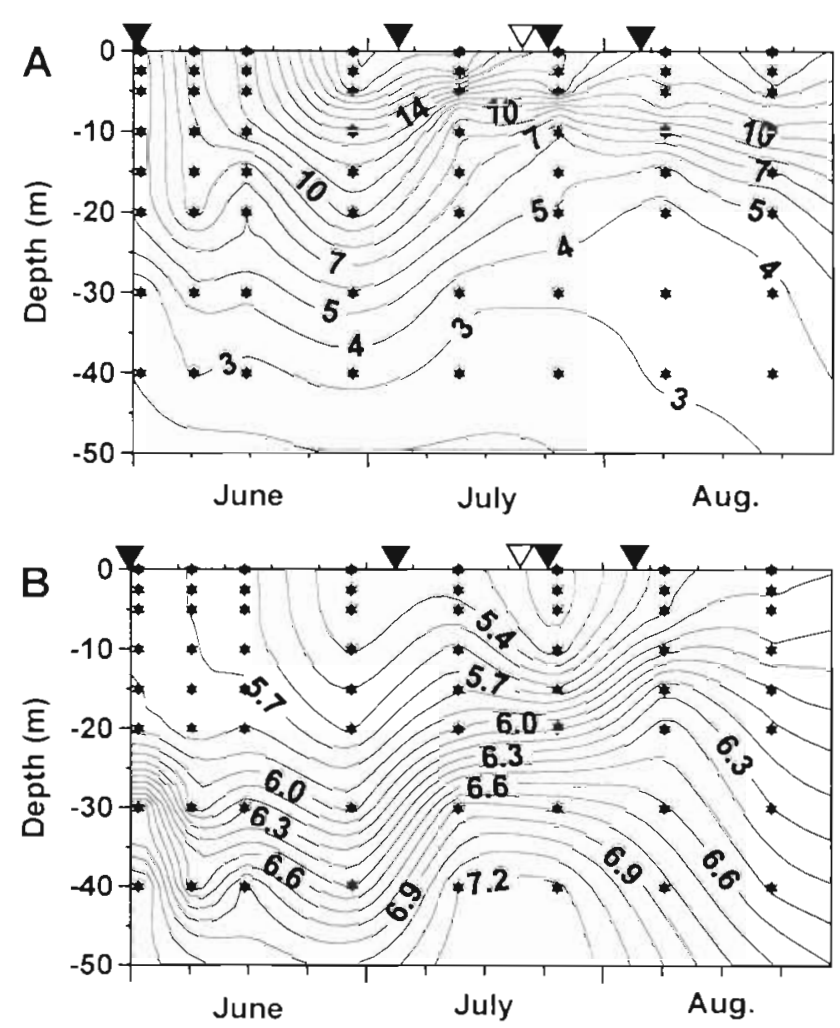

Fig. 1 (A) Temperature and (B) salinity varations in the sea area off Tvärminne in summer 1988. ( $\mathbf{\nabla})$ Upwelling; $(\nabla)$ downwelling (cf. Haapala 1994)

in June and July, in August the share of Acartia spp. and Bosmina longispina maritima (P. E. Müller) increased, causing another biomass maximum. Metazoan microplankton, composed mostly of copepod nauplii and small rotifers Synchaeta spp. and Keratella spp, accounted for 1 to $20 \%$ of the total metazooplankton biomass. Biomass of heterotrophic microprotists was 52 to $126 \mathrm{mg} \mathrm{C} \mathrm{m}^{-2}$, being dominated by Ebria tripartita and heterotrophic dinoflagellates Protoperidinium spp. in June. From July on, the share of oligotrich ciliates, especially Strobilidium spiralis Leegaard and Strombidium spp., increased (Fig. 2C). In August, the biomass of the autotrophic ciliate Mesodinium rubrum Lohmann (Fig. 2A) was as large as that of ciliates, being $125 \mathrm{mg} \mathrm{C} \mathrm{m}^{-2}$. Bacterial biomass was $560 \mathrm{mg} \mathrm{C} \mathrm{m}^{-2}$ on 2 June, but later in the summer it varied between 700 and $1100 \mathrm{mg} \mathrm{C} \mathrm{m} \mathrm{Cm}^{-2}$ (Fig. 2C).

\section{Primary production, herbivory and sedimentation}

Primary productivity was 80 to $370 \mathrm{mg} \mathrm{C} \mathrm{m}^{-2} \mathrm{~d}^{-1}$ (Fig 3), increasing steadily during June and the first half of July, whereafter it decreased strongly at the 


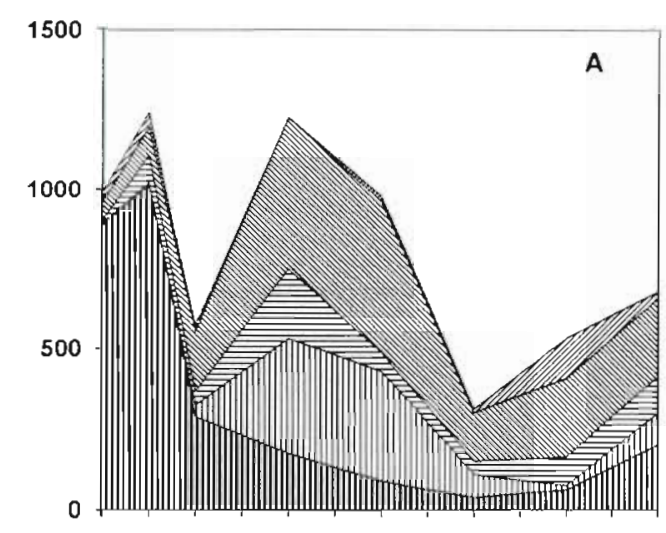

\section{Mesodinium rubrum \\ Picocyanobacteria \\ 目 Filamentous cyanobacteria}

CIII PHYTO 2-10 $\mu \mathrm{m}$

IIII PHYTO $>10 \mu \mathrm{m}$

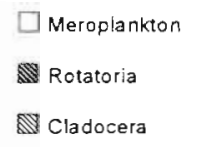

$\mathbb{N}$ Cladocera

들 Copepod nauptii

IIII Eurytemora spp. Cl.CVI

IIII Acartia spo Cl-CVI
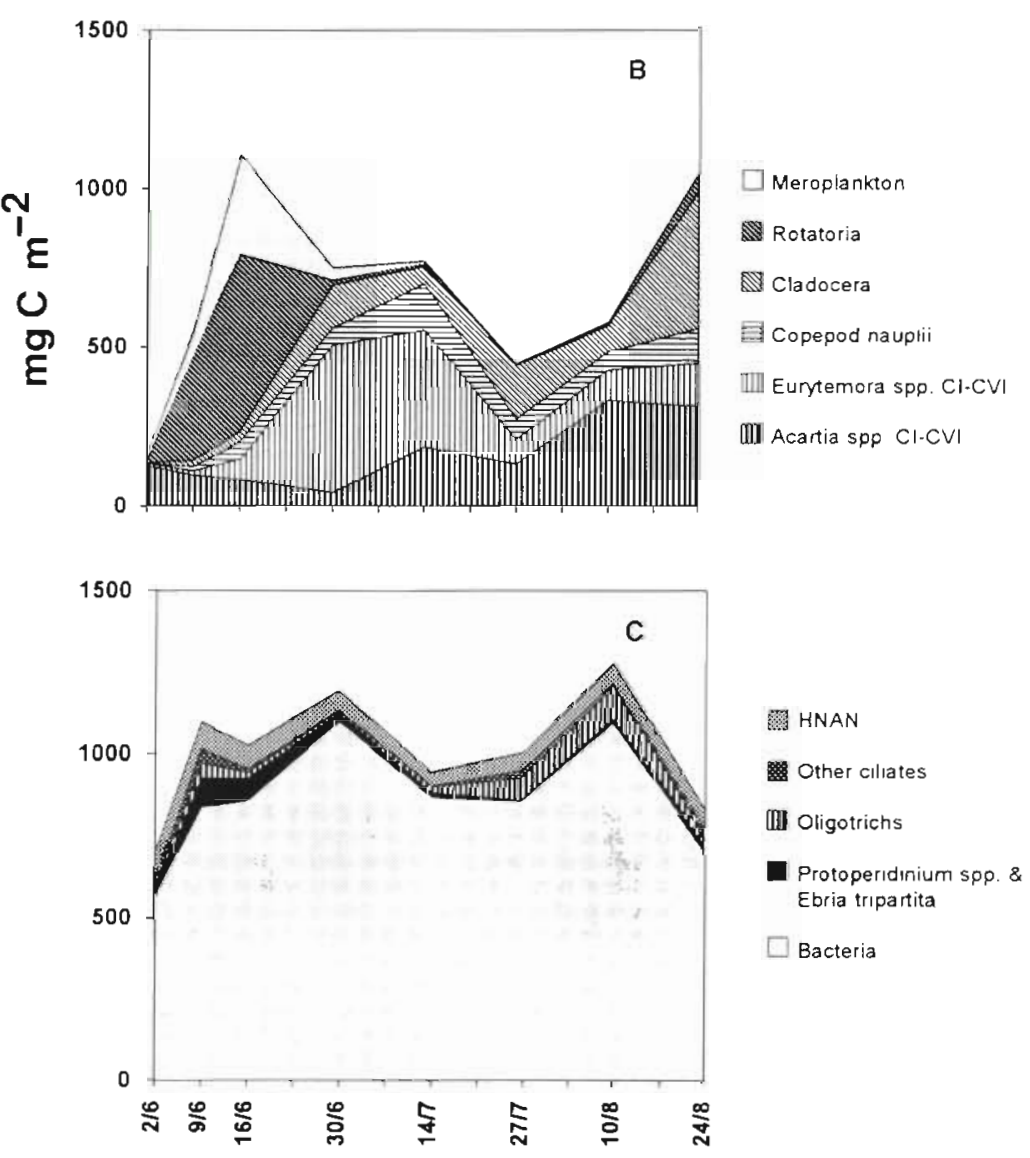

Fig 2. Sucression and development of (A) phytoplankton. (B) metazooplankton, and (C) protozooplankton and bacteria at the sea area off $T$ varminne in summer 1988

same time as phytoplankton biomass declined. A higher rate was found again in August, along with a phytoplankton biomass increase. The estimated primary sedimentation rate was 10 to $350 \mathrm{mg} \mathrm{C} \mathrm{m}^{-2} \mathrm{~d}^{-1}$, reaching its maximum in mid-June, after which it decreased to the end of the summer.

Daily grazing by different trophic groups varied widely during the summer (Fig. 4). HNAN and ciliates grazed most in July, when picocyanobacteria and nanoflagellates dominated the phytoplankton biomass (Figs, 4A, B). Protoperidinium spp. and Ebria tripartita together were estimated to graze most in early June, when phytoplankton $>10 \mu \mathrm{m}$ predominated. Mesozooplankton grazed most in early June, but metazoan microplankton grazed most in July. Grazing on autotrophic Mesodinium rubrum by metazooplankton was estimated to be greatest in August. Total herbivory was 30 to $330 \mathrm{mg} \mathrm{C} \mathrm{m}^{-2} \mathrm{~d}^{-1}$

\section{Heterotrophy and food web dynamics}

Bacteria were estimated to account for 20 to $90 \%$ of the daily HNAN nutrition. Among ciliates, bacteria were estimated to comprise 2 to $34 \%$ of the daily nutrition, the largest percentage occurring in $\mathrm{Au}$ gust (Fig. 4B). In June, up to $80 \%$ of total ciliate nutrition was composed of HNAN, and at the same time the efficiency of the MFW in transferring bacterial carbon to ciliate nutrition was estimated to be $74 \%$ (Table 1). The efficiency of the MFW varied during the summer, but ciliates were estimated to gain a greater amount of bacterial carbon through this 2-step food chain than through direct grazing on bacteria (Fig. 4, Table 1).

Metazooplankton predation on ciliates increased during the summer, accounting for up to $60 \%$ of total ingestion (Fig. 4). In the 2-step MFW ciliates were most important in transferring nanoplanktonic carbon to metazooplankton; as much as $24 \%$ and $21 \%$ of metazooplankton nutrition was composed of 2 to $10 \mu \mathrm{m}$ phytoplankton and HNAN transferred by ciliates in August, respectively (Table 1). Direct grazing on HNAN was more inefficient, corresponding at most to $17 \%$ of metazooplankton total nutrition in June (Fig. 4C). The contribution of picocyanobacterial carbon to metazooplankton nutrition was no more than 5 and $3 \%$, when estimated to have been transferred through the 2-step food chains through ciliates and HNAN, respectively. The contribution of bacteria transferred through the same routes was estimated to be at most 14 and $15 \%$ In addition, as much as 17 and $16 \%$ of picocyanobacterial and bacterial carbon was estimated to have been transferred to metazooplankton nutrition through the 3-step linkage of HNAN and ciliates, respectively (Table 1). 


\section{Detrital carbon and bacterial production}

Total POC varied between 3.8 and $5.6 \mathrm{~g} \mathrm{C} \mathrm{m}^{-2}, \mathrm{DPC}$ accounting for 31 to $62 \%$ of the total (Fig. 5A). The formation ofUDC through the functioning of the pelagic food web was estimated to be highest in August. Primary production (non-consumed phytoplankton + exudation by phytoplankton) was estimated to comprise ca 10 to $70 \%$ of UDC formation, the lowest percentages occurring in July. The respective contribution of metazooplankton (faecal pellets + sloppy feeding) was estimated to be 10 to $60 \%$, being largest in June, when metazooplankton grazed on $>10 \mu \mathrm{m}$ phytoplankton. Non-consumed secondary production of HNAN, microprotists and bacteria was estimated to account for 10 to $50 \%$ of UDC formation, being largest in July when protists were estimated to be most productive. The carbon demand of bacteria was estimated to be 110 to $325 \mathrm{mg} \mathrm{C} \mathrm{m} \mathrm{m}^{-2} \mathrm{~d}^{-1}$. The formation of UDC was estimated to usually meet the daily bacterial carbon requirement, if loss by sedimentation was not taken into account. Bacterial production was 45 to $130 \mathrm{mg} \mathrm{C}$ $\mathrm{m}^{-2} \mathrm{~d}^{-1}$ and both the highest and lowest rates were measured in August (Fig. 5B).

\section{Carbon budget}

The grazing impact of different herbivorous groups varied during the summer (Fig. 6). HNAN were important in late July, when they grazed approximately half of the total daily primary production. The combined daily carbon requirement of microprotozoan Protoperidinium spp. and Ebria tripartita was

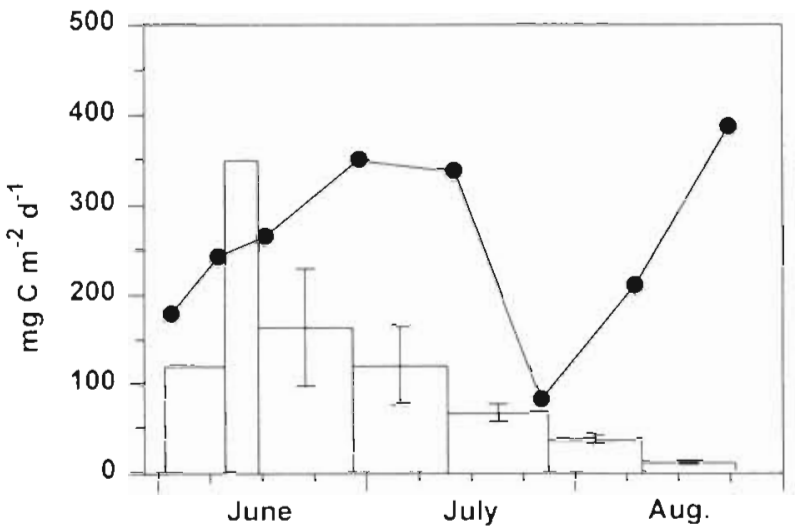

Fig. 3. Primary productivity (line) and mean primary sedimentation (columns): vertical bars show the range between the traps at $15 \mathrm{~m}$ (upper limit) and $30 \mathrm{~m}$ (lower limit) depth

largest in June when it accounted for one quarter of the daily primary production, but at other times $<5 \%$ of was grazed. Ciliates were estimated to directly graze approximately one half of the primary production in mid-July, and up to $11 \%$ was estimated to have been transferred from picocyanobacteria through HNAN to ciliates in August. Metazooplankton directly grazed as much as $64 \%$ of the primary production in June, but up to one quarter of the daily phytoplankton production could be transferred to metazooplankton via 2- and 3-step food chains through HNAN and ciliates from $<10 \mu \mathrm{m}$ phytoplankton during late summer, the nanoalgae $\rightarrow$ ciliate $\rightarrow$ metazooplankton linkage being the most important pathway. Metazooplankton grazing on Mesodinium rubrum was estimated to account for up to $40 \%$ of primary production in August (Fig. 6).

Table 1. Potential efficiency of the 2- and 3-step pelagic food chains in transferring phytoplankton and bacterial biomass to higher trophic levels, expressed as a percentage of carbon transferred to ciliate and metazooplankton nutrition in the sea area during summer 1988. Picocyano: picocyanobacteria; HNAN: heterotrophic nanoflagellates; meta: metazooplankton

\begin{tabular}{|c|c|c|c|c|c|c|c|c|c|c|}
\hline \multirow{2}{*}{$\begin{array}{l}\text { Hydrodynamic period: } \\
\text { Date: }\end{array}$} & \multicolumn{3}{|c|}{ I } & \multicolumn{2}{|c|}{ II } & \multicolumn{3}{|c|}{ III } & \multirow[t]{2}{*}{ Mean } & \multirow[t]{2}{*}{ SD } \\
\hline & $2 / 6$ & $9 / 6$ & $16 / 6$ & $30 / 6$ & $13 / 7$ & $27 / 7$ & $10 / 8$ & $24 / 8$ & & \\
\hline \multicolumn{11}{|l|}{ Ciliates } \\
\hline Picocyano $\rightarrow$ HNAN $\rightarrow$ ciliates & 7 & 7 & 10 & 8 & 7 & 7 & 39 & 27 & 14 & 12 \\
\hline Bacterla $\rightarrow$ HNAN $\rightarrow$ ciliates & 74 & 59 & 46 & 6 & 4 & 27 & 9 & 6 & 29 & 26 \\
\hline \multicolumn{11}{|l|}{ Metazooplankton } \\
\hline Picocyano $\rightarrow$ HNAN $\rightarrow$ meta & $<1$ & $<1$ & 3 & 2 & 2 & 1 & 2 & 5 & 2 & 1 \\
\hline Picocyano $\rightarrow$ ciliates $\rightarrow$ meta & $<1$ & $<1$ & 1 & $<1$ & $<1$ & 2 & 3 & 1 & 1 & 1 \\
\hline Picocyano $\rightarrow$ HNAN $\rightarrow$ ciliates $\rightarrow$ meta & $<1$ & 1 & 2 & $<1$ & $<1$ & 4 & 17 & 7 & 4 & 5 \\
\hline Total & 1 & 1 & 6 & 3 & 3 & 7 & 22 & 13 & 7 & 7 \\
\hline $2-10 \mu \mathrm{m}$ algae $\rightarrow$ ciliates $\rightarrow$ meta & $<1$ & $<1$ & 5 & 5 & 13 & 24 & 4 & 15 & 8 & 8 \\
\hline$>10 \mu \mathrm{m}$ algae $\rightarrow$ Protoperidinium $\rightarrow$ meta & 1 & 3 & 2 & $<1$ & 1 & $<1$ & 1 & $<1$ & 1 & 1 \\
\hline Total & 1 & 4 & 7 & 5 & 13 & 24 & 5 & 16 & 9 & 7 \\
\hline Bacteria $\rightarrow$ HNAN $\rightarrow$ meta & 3 & 2 & 14 & 2 & 1 & 5 & 1 & 1 & 4 & 4 \\
\hline Bacteria $\rightarrow$ ciliates $\rightarrow$ meta & $<1$ & 2 & 2 & $<1$ & $<1$ & 12 & 15 & 2 & 4 & 5 \\
\hline Bacteria $\rightarrow$ HNAN $\rightarrow$ ciliates $\rightarrow$ meta & 3 & 5 & 8 & $<1$ & 1 & 16 & 4 & 2 & 5 & 5 \\
\hline Total & 6 & 9 & 24 & 2 & 2 & 33 & 20 & 5 & 13 & 11 \\
\hline
\end{tabular}



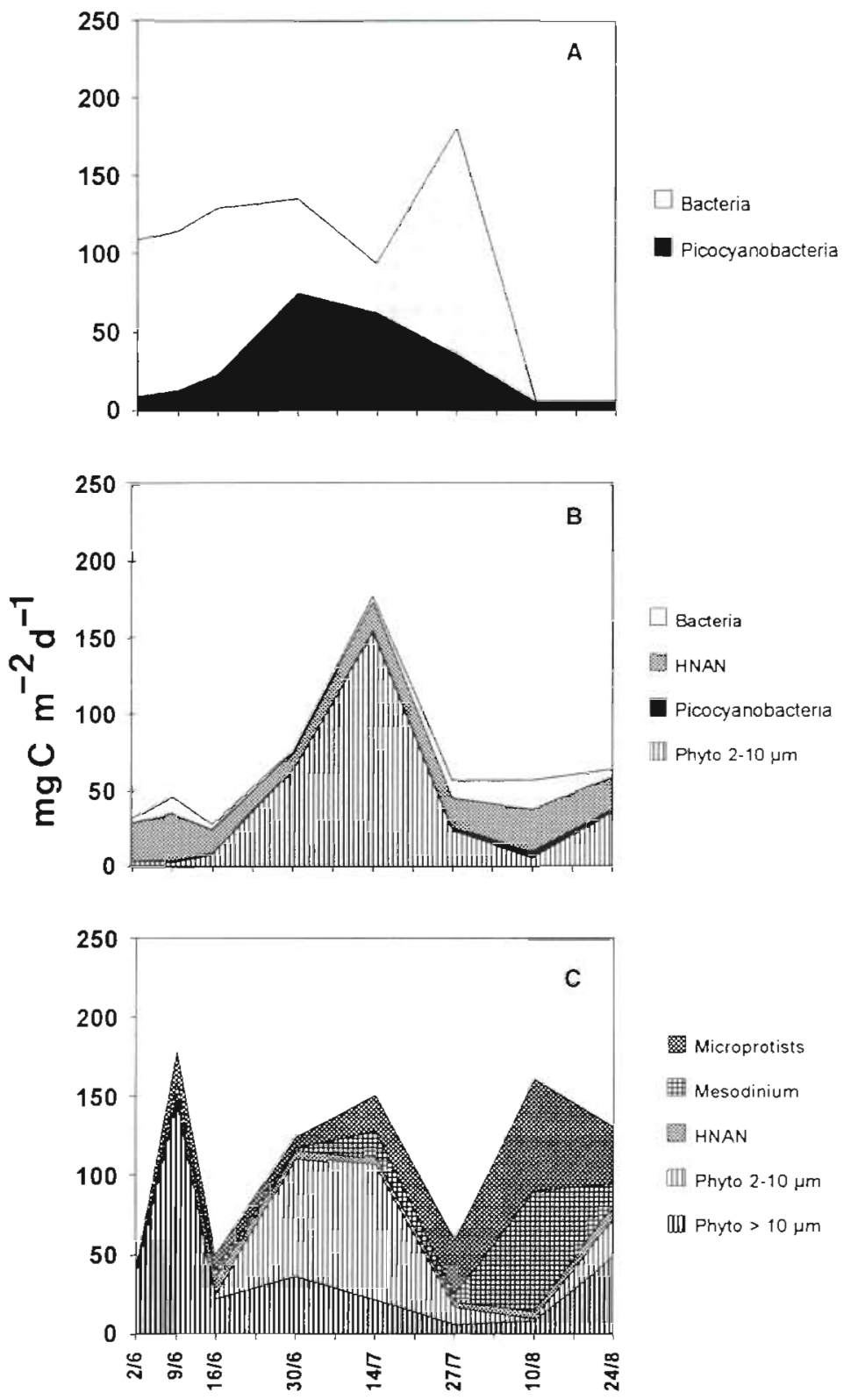

Fig. 4. Ingestion rates of various food sources by (A) HNAN, (B) ciliates and (C) metazooplankton

HNAN were important grazers on bacteria in early June and late July, when their grazing was estimated to exceed the measured bacterial production. Ingestion of bacteria by ciliates was estimated to account for at its highest only $15 \%$ of the bacterial production in. late August. On average, the amount of algal and bacterial carbon that was estimated to have been transferred through the MFW to the daily nutrition of ciliates corresponded to 4 and $16 \%$ of the daily primary and bacterial production, respectively. The corresponding percentages for metazooplankton were as much as 9 and $7 \%$, due to the metazooplankton feeding on HNAN and ciliates.
The summer carbon budget was constructed for the period between 2 June and 27 August (Fig 7 ) by integrating the daily rate measurements. In this carbon budget, primary production was $20.5 \mathrm{~g} \mathrm{C} \mathrm{m}^{-2}$, total herbivory $13.6 \mathrm{~g} \mathrm{C} \mathrm{m}^{-2}$ and estimated primary sedimentation $8.5 \mathrm{~g} \mathrm{C} \mathrm{m}^{-2}$. If the sedimentation loss of early June, composed of mostly the sinking senescent phytoplankton bloom, was excluded from the calculations, summer sedimentation would be $5.7 \mathrm{~g} \mathrm{C} \mathrm{m}^{-2}$. Bacterial production was $8 \mathrm{~g} \mathrm{C} \mathrm{m}^{-2}$, from which protists were estimated to have grazed $5.1 \mathrm{~g} \mathrm{C} \mathrm{m}^{-2}$ (Fig. 7) Carbon release from phytoplankton production to the UDC pool was estimated to be $8.5 \mathrm{~g} \mathrm{C} \mathrm{m}^{-2}$ during the summer, from which non-consumed phytoplankton, phytoplankton exudation and metazoplankton sloppy feeding accounted for 64,25 and $12 \%$, respectively. Formation of metazooplankton faecal pellets was estimated to be $3.9 \mathrm{~g} \mathrm{C} \mathrm{m}^{-2}$ and the release from other trophic groups $5.2 \mathrm{~g} \mathrm{C}$ $\mathrm{m}^{-2}$. If metazooplankton biomass elimination was calculated using the equation $B_{1}+P-B_{2}$, where $B_{1}$ is metazooplankton biomass at time $t_{1}, P$ is the integrated production between times $t_{1}$ and $t_{2}$, and $B_{2}$ is metazooplankton biomass at time $t_{2}$, total elimination would be $2.3 \mathrm{~g} \mathrm{C} \mathrm{m}^{-2}$, i.e. the carbon potentially available to zooplanktivores or recycled within the community in summer.

\section{DISCUSSION}

\section{Hydrodynamic periods and food web dynamics}

Hydrodynamic conditions, mainly the degree of stratification and upwellings in late July and early August, strongly affected the planktonic community, consequently 3 different stages of food web dynamics could be distinguished. All trophic groups were largely omnivorous, but the role of different carbon pathways varied during the summer In early June, the remains of the vernal phytoplankton community and large amounts of detrital carbon prevailed in the water column. Assuming a rough growth yield of 30 to $40 \%$ for metazooplankton (Mullin \& Brooks 1970, Durbin \& Durbin 1992), the integrated total ingestion of naturally occurring phytoplankton and protists could meet approximately 30 to $50 \%$ of the community's carbon demand, the rest being possibly fulfilled by ingestion on detritus in early June. Bacterial carbon was important for HNAN nutrition, 

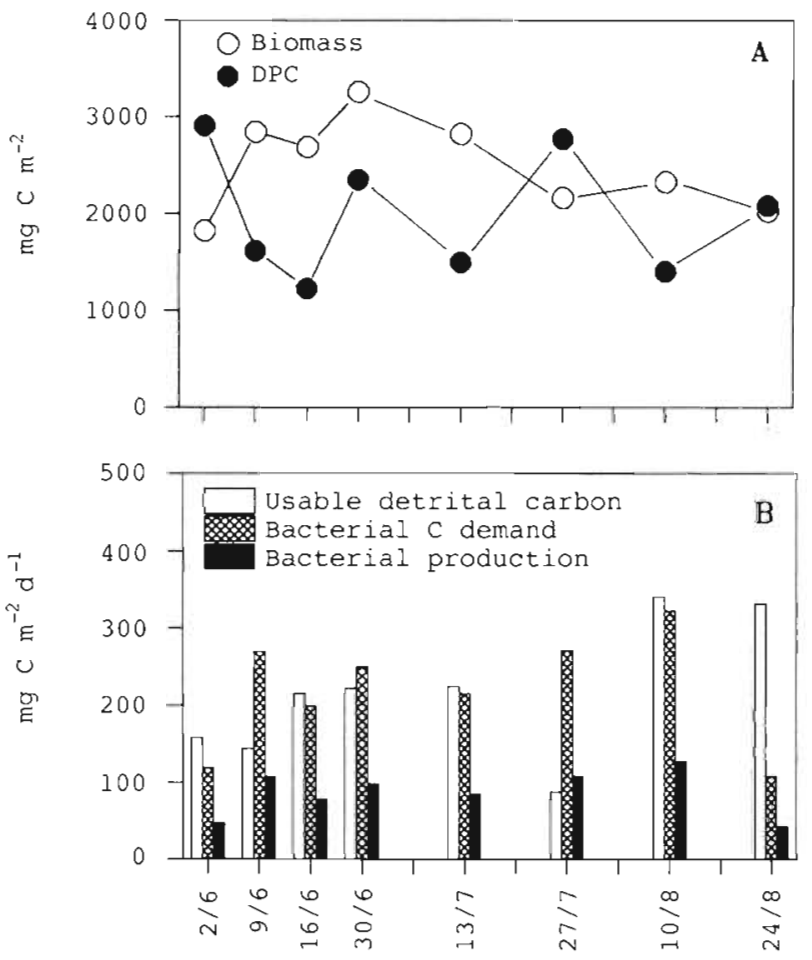

Fig. 5. (A) Development of total blomass and detrital particulate carbon (DPC), and (B) estimated usable detrital carbon (UDC) released from the food web, estimated bacterial carbon demand and measured bacterial production

which is in accordance with previous studies done in the area (Kuosa \& Kivi 1989, Kuuppo-Leinikki 1990) and with the studies from other marine areas (Wigner \& Hagström 1988, Sanders et al. 1992). A considerable amount of bacterial carbon was also transferred to ciliate nutrition through the MFW. The large amount of DPC probably provided usable compounds for bacteria, whose biomass increased in spite of a severe predation pressure by HNAN.

In late June and in July, the warm and stratified period was characterised by the dominance of autotrophic picoplankton and nanoflagellates, and microprotozoan biomass was at its lowest level, whereas mesozooplankton biomass increased. Unlike early June, all trophic groups were largely herbivorous. Metazooplankton fed also on ciliates, that transferred nanoplanktonic carbon. There seemed to be a balance between the formation of UDC and bacterial carbon requirements, indicating that the mid-summer community recycled carbon within the pelagic ecosystem.

The third period began when surface water currents and wind-induced upwellings in late July weakened thermal stratification and strongly affected the planktonic community. Primary productivity, the biomass of phytoplankton and the biomass of metazooplankton decreased. Ciliates and metazooplankton fed largely on heterotrophs, thus both bacterial and algal carbon were transferred to metazooplankton with the highest rate. After the first part of August, no major perturbations occurred and stratification was re-established. The formation of UDC exceeded the carbon demand of bacteria at the end of August, but no increase in sedimentation was observed. The biomass of Aphanizomenon cf. flos-aquae increased in August. This filamentous cyanobacteria is not palatable to metazooplankton (Sellner et al. 1994), hence the degradation of this species could have caused the increase in UDC.

Picoplankton was not an important food source for ciliates, accounting on average for $17 \%$ of the their total nutrition. However, picocyanobacteria are known to form colonies of approximately 10 cells (Kuosa 1988), which may be eaten by ciliates. Herbivory was the major feeding mode for metazooplankton, but feeding on ciliates increased throughout the summer, reflecting the increasing role of the MFW in metazoan nutrition. Ingestion by metazooplankton of carbon ariginating from picoplankton was small, depending mostly on the percentage of ciliates in metazooplankton food, and on the concurrent ciliate diet. The daily efficiency of picoplanktonic carbon transfer through the 3 -step food chain was low; on average 4 and $5 \%$ of metazooplankton nutrition was composed of transferred picocyanobacterial and bacterial carbon respectively, which is in accordance with other studies on the MFW efficiency (Ducklow et al, 1986, Hagström et al. 1988, Wikner \& Hagström 1988). However, a slightly smaller amount of picoplanktonic carbon was also
Ingestion on autotrophs, \% of PP

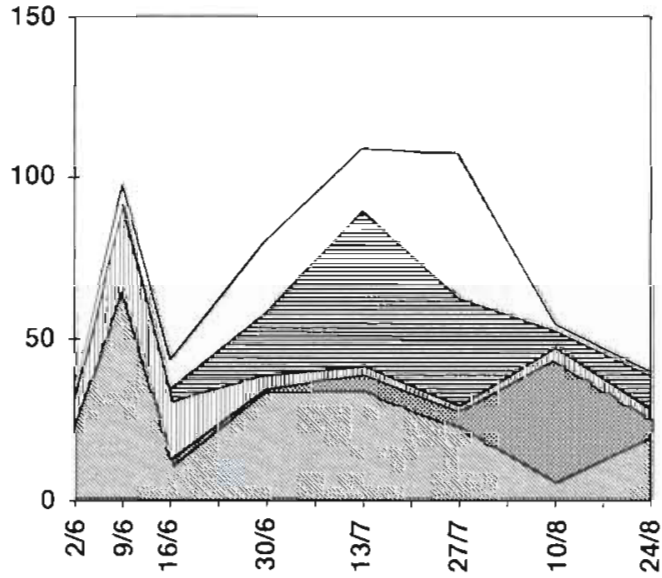

Fig. 6. Estimated ingestion of autotrophs by herbivorous trophıc groups, expressed as a percentage of the daily primary production. G: grazing 


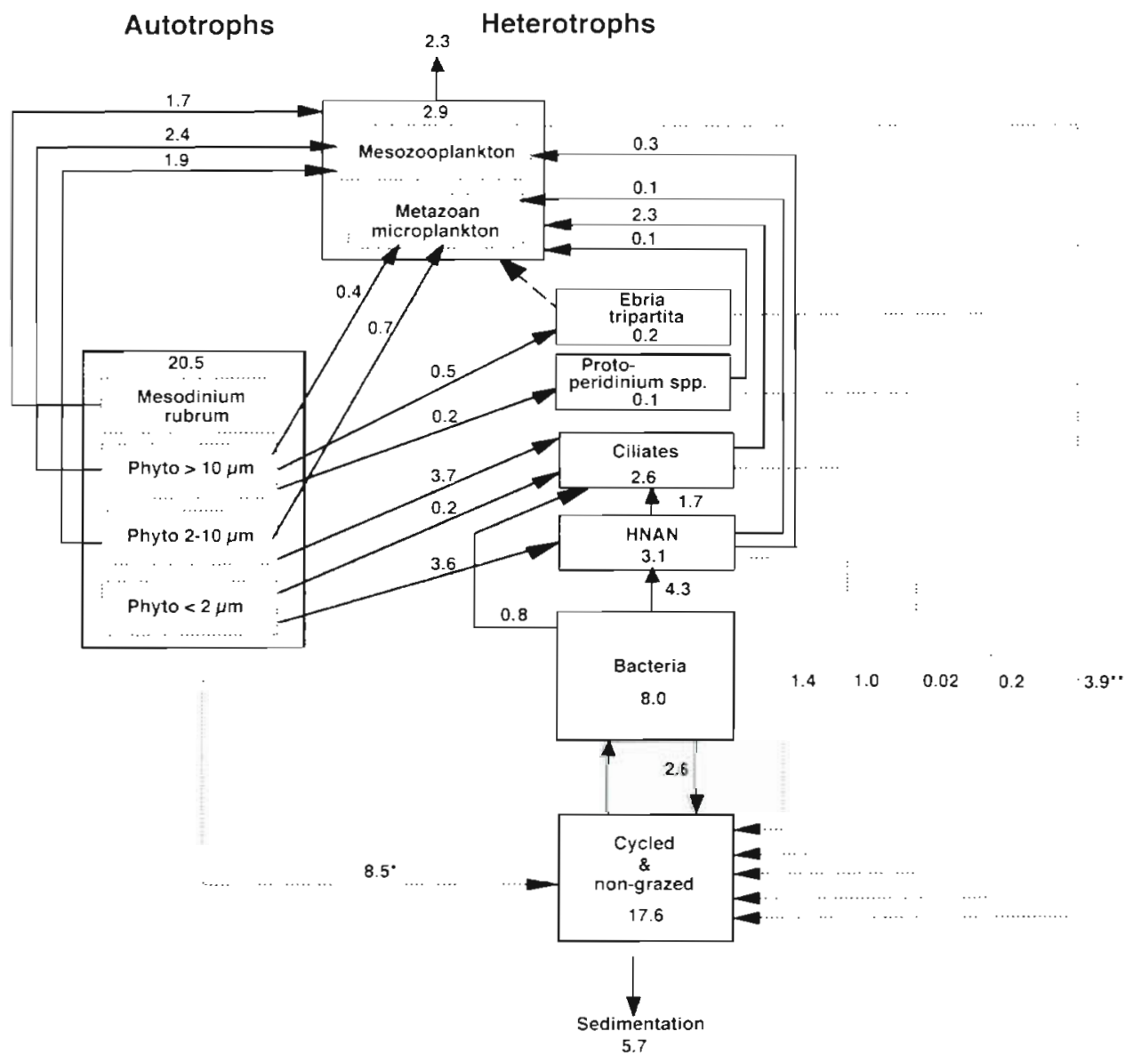

Fig. 7. Carbon flow analysis of the pelagic community in the Tvärminne sea area, integrated values between 2 June and 28 August 1988. Values in boxes: production; continuous line with arrow: ingestion; dotted line: recycled carbon (g C m $\mathrm{m}^{-2}$ period $^{-1}$ ). "non-grazed phytoplankton carbon + phytoplankton exudation + metazooplankton sloppy feeding; "*metazooplankton faecal pellets transferred through 2-step chains, i.e. through HNAN and ciliates, thus increasing total picocyanobacterial and bacterial carbon transfer to 7 and $13 \%$ of metazooplankton nutrition, respectively.

\section{Alternative carbon pathways}

HNAN were estimated to satisfy $56 \%$ of their carbon demand with picophytoplankton, which agrees with values previously measured by Kuosa \& Kivi (1989). Flagellates $>5 \mu \mathrm{m}$ are also known to ingest small nanoplanktonic organisms (Kuosa 1990, Sherr \& Sherr 1992), whose role, however, could not be estimated in this study. In addition, choanoflagellates at least are also known to utilise detrital particles as food (Marchant \& Scott 1993, Tranvik et al. 1993), which is also an alternative carbon pathway to higher trophic groups.

In many recent studies, athecate phagotrophic gymnodinoid and katodinoid dinoflagellates have been found to be efficient grazers of nanoplankton (Bjernsen \& Kuparinen 1991, Hansen 1991, Strom 1991, Neuer \& Cowles 1994). Unfortunately, phagotrophic species could not be distinguished from autotrophic dinoflagellates in this study, and only a rough estimation of the role of the potentially phagotrophous genera Gymnodinium, Gyrodinium, Glenodinium and Katodinium (Neuer \& Cowles 1994, Sherr \& Sherr 1994) could be carried out. The combined biomass of these dinoflagellates was ca 100 to $400 \mathrm{mg} \mathrm{C} \mathrm{m}^{-2}$ in June, but decreased to $<20 \mathrm{mg} \mathrm{C} \mathrm{m}^{-2}$ in late summer. That biomass accounted for as much as $30 \%$ of the total phytoplankton biomass and $150 \%$ of the microprotozoan biomass in early June. Assuming that all species of these genera were heterotrophic, their daily carbon ingestion would be 20 to $110 \mathrm{mg} \mathrm{C} \mathrm{m}^{-2}$ in June, if the carbon demand was calculated in the same way as for Protoperidinium spp. This emphasises the large potential grazing impact of these potentially heterotrophic dinoflagellates, being similar to that of Protoperidinium spp. As most of these dinoflagellates were 20 to $30 \mu \mathrm{m}$ in size, they were likely to use the same food as ciliates (Sherr \& Sherr 1992). Potentially heterotrophic dinoflagellates contributed 20 to $40 \%$ to the edible phytoplankton biomass in June, and unlike Ebria tripartita (Kivi et al. 1996), athecate species were probably grazed by metazooplankton. Thus the efficiency of 
the MFW in transferring bacterial and algal carbon to metazooplankton could have been higher than was estimated in June. In late summer, the percentage of athecate dinoflagellates was usually $<10 \%$ of the edible phytoplankton biomass, and thus their role in the carbon transfer was apparently minor.

Mixotrophic nanoflagellates may also have increased ingestion on picoplankton and small nanoplankton during the summer minimum stage. From July onwards, phytoplankton biomass was composed mostly of the potentially mixotrophic species Chrysochromulina spp., unidentified cryptomonads and Pseudopedinella sp. (Kuosa 1990, Turner \& Roff 1993). According to Andersson et al. (1994), the growth of mixotrophic algae may explain flagellate peaks coinciding with the late summer peak in bacterial production in coastal areas of the northern Baltic. If mixotrophic organisms are able to graze at significant rates, the efficiency of the MFW in transferring picoplanktonic carbon to higher trophic levels is likely to be higher than previously stated.

\section{Carbon budget}

Generally, seasonal succession of phytoplankton, protists and metazooplankton followed the pattern described in previous studies of this area (Niemi 1975 Forsskảhl \& Sundberg 1981, Huttunen \& Kuparinen 1986, Viitasalo 1992, Kuuppo-Leinikki 1993). Primary productivity and bacterial production were also found to be at the levels measured earlier by Kuparinen (1984), Kuosa \& Kivi (1989) and Lignell (1990). This indicates that the general pattern of the summer carbon budget of this study was representative for this coastal area of SW Finland.

On a seasonal basis, differences in the structure of the pelagic community and in the main carbon flows were large. In the study carried out during the preceding cooler and non-stratified spring period, phytoplankton was dominated by large diatoms and $70 \%$ of primary production was estimated to sink, whereas the role of grazing was minor in the study area (Lignell et al. 1993). During summer, temperature, stratification and upwellings influenced community composition and dynamics, and most of the primary production was recycled. When the 2 first sampling periods in early June were left out from the calculations, the total integrated primary sedimentation corresponded to $27 \%$ of the integrated primary production (Fig 7 ), which is slightly higher than the other summer estimates in the Baltic Sea (Kuparinen et al. 1984, Smetacek et al. 1984 Heiskanen \& Leppänen 1995). Sedimentation did not correlate with the amount of total metazooplankton ingestion and with the estimated formation of faecal pel- lets, which implies that faecal material was mostly recycled within the water column. However, sedimentation correlated significantly with metazooplankton grazing on phytoplankton $>10 \mu \mathrm{m}$, and it is possible that pellets formed during June sank. If coprophagy is not important, faecal pellets can sink quickly, which has also been noticed in POC sedimentation rates (Voss 1991). Faecal material of cladocerans is usually recycled within the pelagic community (Elser et al. 1995).

Using integrated values, HNAN grazing on cyanobacteria accounted for $19 \%$ of primary production in summer 1986 (Kuosa 1991), being similar to the $18 \%$ of this study. HNAN are known to also use picoeucaryotic algae as food, and the total grazing by HNAN was estimated to account for $32 \%$ of summer primary production by Kuosa (1991). No previous measurements on summer herbivory of the microprotist community were available from our study area. The estimated $23 \%$ grazing of primary production is within the range found in coastal waters off Washington, USA (17 to $52 \%$; Landry \& Hassett 1982) but lower than the 37 to $115 \%$ found in the coastal area of the eastern Canadian Arctic (Paranjape 1987). As a whole, HNAN and microprotists were estimated to graze on total phytoplankton more than metazooplankton, emphasising their importance in controlling phytoplankton and in the functioning of pelagic food webs in general (Azam et al. 1983). For metazooplankton, the $26 \%$ grazing of primary production is close to the $19 \%$ measured by Uitto (1996a) at $5 \mathrm{~m}$ depth in the same study area, and within the range of 5 to $48 \%$ found in the southern Baltic (Tiselius 1988) or the 14 to $31 \%$ in the Dogger Bank area of the North Sea (Nielsen et al. 1993).

Production by bacteria, HNAN, microprotists and metazooplankton was estimated to account for 39,15 , 14 and $14 \%$ of primary production, respectively, when integrated throughout the summer. If the results of this study are combined with those measured the previous spring (Lignell et al. 1993), the integrated metazooplankton production would be $4 \mathrm{~g} \mathrm{C} \mathrm{m}^{-2}$ for the period from March to August, which is 2 times larger than that estimated by Koski (1995) in 1992 for copepods only, in the same study area. The integrated metazooplankton production for the whole spring and summer period would be $6 \%$ of primary production, which is similar to the earlier estimates for copepods in the northern Baltic (Johansson 1992). Pelagic clupeid fish and mysid shrimp are the most important predators of metazooplankton in the northern Baltic (Rudstam et al. 1992, Uitto et al. 1995), although their grazing impact is largely restricted to the late summer-autumn period (Rudstam et al. 1992).

HNAN were practically the only grazers on bacteria; approximately $53 \%$ of bacterial production was estimated to have been grazed by HNAN, the contribution 
of ciliates being only $11 \%$ On the other hand, Kuosa \& Kivi (1989) estimated that summer bacterial production was not able to sustain the total carbon demand of HNAN, which suggests large interannual variability. Calculated as a percentage of primary production, $25 \%$ of the cycled carbon re-entered the food web as bacterial carbon, mostly as food of $\operatorname{HNAN}$ (Fig. 7). On average, the produced and recycled carbon within the food web could sustain dajly bacterial carbon demand. UDC can be released from algae and protists by passive diffusion or egestion through cell membranes, by sloppy feeding of metazooplankton and by protists that can produce nonliving sub-micrometer particles during grazing (Hagström et al. 1988, Jumars et al. 1989. Lignell 1990, Nagata \& Kirchman 1992). Autolysis caused by abiotic factors (Cole et al. 1984) and by viral infections (Bratbak et al. 1992) is another potential source of UDC. In the more open sea area of the Baltic Sea, autochthonous carbon released by heterotrophic organisms is considered to form the dominant carbon source for bacterial production (Kuparinen \& Heinänen 1993).

\section{Reliability of the estimates}

The carbon budget and estimated flow dynamics are exposed to some error factors due to the use of constant carbon conversion factors and growth yields. The food web structure is also likely to be more complicated than presented in this study, especially within protists. Spatial and temporal patchiness of plankton, as well as variations in the feeding behaviour of planktonic organisms, can cause undetectable error in the carbon flow estimation within the euphotic layer However, daily differences in the food chain efficiency (Table 1) were large enough to suggest temporal variation in the carbon flow dynamics during summer, at least between different hydrodynamic periods.

Most of the grazing measurements were carried out during the same summer, which improves the reliability of the daily flow analysis. One indication of the rough balance of the carbon budget is that the summer primary production was estimated to meet the loss factors caused by herbivory and sedimentation. However, 20 to $40 \%$ of the bacterial carbon demand remained unresolved, depending on whether the summer sedimentation was integrated at $15 \mathrm{~m}\left(9.7 \mathrm{~g} \mathrm{C} \mathrm{m}^{-2}\right.$ period $\left.{ }^{-1}\right)$ or $30 \mathrm{~m}$ trap measurements $\left(4.5 \mathrm{~g} \mathrm{C} \mathrm{m}^{-2}\right.$ period $\left.{ }^{-1}\right)$, and whether the whole metazooplankton production was assumed to have been recycled or consumed by zooplanktivores. Allochthonous carbon is a potential reason for high bacterial production in the coastal area off Tvärminne (Kuosa \& Kivi 1989, Lignell 1990, Lignell et al. 1993), but its importance has not been studied.
This study has produced evidence to support the conclusion that the summer structure and dynamics of the pelagic food web are largely 'multivorous' (sensu Legendre \& Rassoulzadegan 1995), where both herbivory and MFW have significant roles, and where picoplankton is mostly consumed by HNAN and nanoplankton by ciliates and metazooplankton. Ciliates appeared to be an important food source for metazooplankton during summer, which is in accordance with the study of Painting et al. (1993), which found mesozooplankton to be equally dependent on microprotists and phytoplankton during periods when phytoplankton was prectominated by small cells, unavailable to metazooplankton. The pelagic food steps seemed to be loosely coupled and usable detrital carbon released from different trophic groups could sustain bacterial production. Upwellings seemed to have the most powerful effect on the stabile summer pelagic community, emphasising the important role of hydrodynamic events, regulated mainly by regional weather conditions, in modifying the functioning of the whole pelagic ecosystem.

Acknowledgements. This study was carried out under the project PELAG at the Tvärmınne Zoological Station. We wish to thank Drs Kuparinen and Katajisto for bacterial production measurements and the staff of Tvarminne Zoological Station for help during the fiejd work. Marıa Ekman-Ekebom helped in correcting the English. Financial support from the Walter and Andrée de Nottbeck Foundation and the Academy of Finland is acknowledged

\section{LITERATURE CITED}

Andersson A, Haecky P, Hagström Å (1994) Effect of temperature and light on the growth of micro- nano-and picoplankton: impact on algal succession. Mar Biol 120 $511-520$

Autio R, Kuparinen J, Kaitala S (1988) Factorial experments used to analyse nutrient and grazing control of phyto- and bacterioplankton. Arch Hydrobiol Beih Ergebn Limnol 31: $253-263$

Azam F, Fenchel T, Field JG, Gray JS, Meyer-Reil LA, Thingstad F (1983) The ecological role of water-column microbes in the sea. Mar Ecol Prog Ser 10:257-263

Bjørnsen PK, Kuparinen J (1991) Growth and herbivory by heterotrophic dinoflagellates in the: South Ocean, studied by microcosm expenment. Mar Biol 109:397-405

Bratbak $G$, Heldal $M$, Thingstad TF, Riemann $B$, Haslund $O H$ (1992) Incorporation of viruses into the budget of microbial C-transfer. A first approach. Mar Ecol Prog Ser 83: $273-280$

Cole JJ, Likens GE, Hobbie JE (1984) Decomposition of planktonic algae in an oligotrophic lake. Oikos 42:257-266

Ducklow HW, Purdie DA, Williams PJleB, Davies JM (1986) Bacterioplankton: a sink for carbon in a coastal marine plankton community. Science 232:865-867

Durbin EG, Durbin AG (1992) Effects of temperature and food abundance on grazing and short-term weight change in the marine copepod Acartia hudsonica. Limnol Oceanogr 37:361-378 
Edler L (ed) (1979) Recommendations on methods for marine biological studies in the Baltic Sea. Phytoplankton and chlorophyll. Baltic Manne Biologists Publ 5:1-38

Elser J, Foster D, Hecky R (1995) Effects of zooplankton on sedimentation in pelagic ecosystem: theory and test in two lakes of the Canadian shield. Biogeochemistry 30:143-170

Fenchel T (1982) Ecology of heterotrophic microflagellates. II Bioenergetics and growth. Mar Ecol Prog Ser 8:225-231

Forsskăhl M, Sundberg A (1981) Abundance, biomass, species composition of phyto- and zooplankton and their interrelations at the entrance of the Gulf of Finland. Meri 9:43-55

Fuhrman J, Azam F (1980) Bacterioplankton secondary production estimates for coastal waters of British Columbia, Antarctica and California. Appl Environ Microbiol 39: 1085-1095

Fuhrman J, Azam F (1982) Thymidine incorporation as a measure of heterotrophic bacterioplankton production in marine surface waters: evaluation and field results. Mar Biol 66:109-120

Haapala J (1994) Upwelling and its influence on nutrient concentration in the coastal area of the Hanko Peninsula, entrance of the Gulf of Finland. Estuar Coast Shelf Sci 38: $507-521$

Hagstrom $\AA$, Azam F, Andersson A, Wikner J, Rassoulzadegan $F$ (1988) Microbial loop in an oligotrophic pelagic marine ecosystem: possible roles of cyanobacteria and nanoflagellates in the organic fluxes. Mar Ecol Prog Ser 49:171-178

Hansen, PJ (1991) Quantitative importance and trophic role of heterotrophic dinoflagellates in a coastal pelagic food web. Mar Ecol Prog Ser 73:253-261

Heinänen A (1992) Bacteroplankton in the open Baltic Sea. Finn Mar Res 260:3-30

Heiskanen AS (1995) Contamination of sediment trap fluxes by vertically migrating phototrophic micro-organisms in the coastal Baltic Sea. Mar Ecol Prog Ser 122:45-58

Heiskanen AS, Leppänen JM (1995) Estimation of export production in the coastal Baltic Sed: effect of resuspension and microbial decomposition on sedimentation measurements. Hydrobiologia 316:211-224

Hobbie JE, Daley RJ, Jasper S (1977) Use of nuclepore filters for counting bacteria by fluorescence microscopy. Appl Environ Microbiol 33:1225-1228

Huttunen M, Kuparinen J (1986) Species succession and productivity of ultraphytoplankton in the pelagic off Tvärminne, SW coast of Finland. Ophelia Suppl 4:73-83

Jacobson DM. Anderson DM (1986) Thecate heterotrophic dinoflagellates: feeding behavior and mechanisms. J Phycol 22:249-258

Johansson S (1992) Regulating factors for coastal zooplankton communities in relation to eutrophication. PhD thesis, Univ of Stockholm

Jumars PA, Pendry DL, Baross JA, Perry MJ, Frost BW (1989) Closing the microbial loop: dissolved carbon pathway to heterotrophic bacteria from incomplete ingestion, digestion and absorption in animals. Deep Sea Res 36:483-495

Kivi K (1996) On the ecology of planktonic microprotozoans in the Gulf of Finland, northern Baltic Sea. W \& A de Nottbeck Foundation Sci Rep 11:1-36

Kıvi K, Kuosa H, Tanskanen S (1996) An experimental study on the role of crustacean and microprotozoan grazers in the planktonic food web. Mar Ecol Prog Ser 136:59-68

Kivi K, Setälä O (1995) Simultaneous measurement of food particle selection and clearance rate of planktonic oligotrich ciliates (Clliophora: Oligotrichina). Mar Ecol Prog Ser 119:125-137
Kononen K, Forsskå̉hl M, Huttunen M, Sandell M, Viljamaa $\mathrm{H}$ (1984) Practical problems encountered in phytoplankton cell volume calculations using the $\mathrm{BMB}$ recommendation in the Gulf of Finland. Limnologica 15:605-614

Kononen K, Kuparinen J, Mäkelä K, Laanemets J, Pavelson J (1996) Initiation of cyanobacterial blooms in frontal region at the entrance to the Gulf of Finland, Baltic Sea. Limnol Oceanogr 41:92-112

Koski M (1995) Seasonal development of metazooplankton population density, biomass and production in the SW coast of Finland. Ph Lic thesis, Univ of Helsinki

Kuosa $H$ (1988) Occurrence of autotrophic picoplankton along an open sea-inner archipelago gradient in the Gulf of Finland, Baltic Sea. Ophelia 28:85-93

Kuosa $H$ (1990) Protozoan grazing on pico- and nanophytoplankton in the northern Baltic Sea: direct evidence from epifluorescence microscopy. Arch Hydrobiol 119:257-265

Kuosa H (1991) Picoplanktonic algae in the northern Baltic Sea: seasonal dynamics and flagellate grazing. Mar Ecol Prog Ser 73:269-276

Kuosa H, Kivi K (1989) Bacteria and heterotrophic flagellates in the pelagic carbon cycle in the northern Baltic Sea. Mar Ecol Prog Ser 53:93-100

Kuparinen $J$ (1984) Annual and seasonal fluctuation of primary productivity and overall respiration in a pelagic plankton community off Tvärminne, SW coast of Finland. Ophelia Suppl 2:111-122

Kuparinen J (1988) Development of bacterioplankton during winter and early spring at the entrance to the Gulf of Finland, the Baltuc Sea. Ver Int Verein Limnol 23:1869-1878

Kuparinen J, Leppänen JM, Sarvala J, Sundberg A, Virtanen A (1984) Production and utilization of organic matter in a Baltic ecosystem off Tvärminne, southwest coast of Finland. Rapp P-V Réun Cons lnt Explor Mer 193:180-192

Kuparinen J, Heinänen A (1993) Inorganic nutrient and carbon controlled bacterioplankton growth in the Baltic Sea. Estuar Coast Shelf Sci 37:271-285

Kuuppo-Leinikki P (1990) Protozoan grazing on planktonic bacteria and its impact on bacterial production. Mar Ecol Prog Ser 63:227-238

Kuuppo-Leinikki P (1993) Horizontal distribution of phytoplankton and heterotrophic micro-organisms on the coastal area of the northern Baltic Sea - a case study. J Plankton Res 15:27-35

Lampert W (1978) Release of dissolved organic carbon by grazing zooplankton. Limnol Oceanogr 23:831-834

Landry MR, Hassett RP (1982) Estimating the grazing impact of marine microplankton. Mar Biol 67:283-288

Laws EA, Bienfang PK, Ziemann DA, Conquest JD (1988) Phytoplankton population dynamics and the fate of production during spring bloom in Auke Bay, Alaska. Limnol Oceanogr 33:57-65

Legendre L, Rassoulzadegan F (1995) Plankton and nutrient dynamics in marine waters. Ophelia 41:153-172

Lignell R (1990) Excretion of organic carbon by phytoplankton: its relation to algal biomass, primary productivity and bacterial secondary productivity in the Baltic Sea. Mar Ecol Prog Ser 68:85-99

Lignell R, Heiskanen AS, Kuosa H, Gundersen K, KuuppoLeinikki P, Pajuniemi R, Uitto A (1993) Fate of a phytoplankton spring bloom: sedimentation and carbon flow in the planktonic food web in the northern Baltic. Mar Ecol Prog Ser 94:339-252

Lignell R, Kaitala S, Kuosa H (1992) Factors controlling phytoand bacterioplankton in late spring on a salinity gradient in the northern Baltic. Mar Ecol Prog Ser 84:121-131

Marchant HJ, Scott. FJ (1993) Uptake of sub-micrometre par- 
ticles and dissolved organic matenal by Antarctic choanoflagellates. Mar Ecol Prog Ser 92:59-64

Moloney CL, Field JG (1989) General allometric equations for rates of nutrient uptake, ingestion and respiration in plankton organısms. Limnol Oceanogr 34:1290-1299

Mullın MM (1969) Production of zooplankton in the ocean: the present status and problems. Oceanogr Mar Biol Annu Rev 7:293-310

Mullin MM, Brooks ER (1970) The ecology of the plankton off La Jolla, California in the period April through September, 1967 Part VII. Production of planktonic copepod, Calanus helgolandicus. Bull Scripps Inst Oceanogr 17: $89-103$

Nagata T, Kirchman DL (1992) Release of dissolved matter by heterotrophic protozoa: implications for microbial food webs. Arch Hydrobiol Beih Ergebn Limnol 32:99-109

Neuer S, Cowles TJ (1994) Protist herbivory in the Oregon upwelling system. Mar Ecol Prog Ser 113:147-162

Nielsen TG, Lokkegaard B, Richardson K, Pedersen FB, Hansen L (1993) Structure of plankton communities in the Dogger Bank (North Sea) during a stratified situation. Mar Ecol Prog Ser 95:115-131

Niemi $\AA$ (1973) Ecology of phytoplankton in the Tvärminne area, SW coast of. Finland. I. Dynamics of hydrography, nutrients, chlorophyll $a$ and phytoplankton. Acta Bot Fenn 100:1-68

Niemi $\AA$ (1975) Ecology of phytoplankton in the Tvärmınne area, SW coast of Finland. II. Primary production and environmental conditions in the archipelago and the sea zone Acta Bot Fenn 105:1-73

Niemi M, Kuparinen J, Uusi-Rauva A, Korhonen K (1983) Preparation of algal samples for liquid scintillation counting. Hydrobiologia 106:149-15

Painting SJ, Moloney CL, Lucas MI (1993) Simulation and field measurements of phytoplankton-bacteria-zooplankton interactions in the southern Benguela upwelling region. Mar Ecol Prog Ser 100:55-69

Paranjape MA (1987) Grazing by microzooplankton in the eastern Canadian arctic in summer 1983. Mar Ecol Prog Ser 40:239-246

Pomeroy LR, Wiebe WJ (1988) Energetics of microbial food webs. Hydrobiologia 159:7-18

Rassoulzadegan F (1993) Protozoan patterns in the AzamAmmermans's bacteria-phytoplankton mutualısm. In Guerrero R, Pedros-Alio C (eds) Trends in microbral ecology. Spanish Society for Microbiology, Barcelona, p $435-439$

Riemann B, Bjørnsen PK, Newell S, Fallen R (1987) Calculation of all production of coastal manne bacteria based on measured incorporation of $\left.\left.\right|^{3} \mathrm{H}\right]$ thymidine. Limnol Oceanogr $32: 471-476$

Rudstam LG, Hansson S, Johansson S, Larsson U 11992 Dynamics of planktivory in a coastal area of the northern Baltic Sea. Mar Ecol Prog Ser 80:159-173

Sanders RW, Caron DA, Berninger UG (1992) Relationships between bacteria and heterotrophic nanoplankton in marine fresh waters: an inter-ecosystem comparison. Mar Ecol Prog Ser 86:1-14

Sellner KG, Olson MM, Kononen K (1994) Copepod grazing in a summer cyanobacteria bloom in the Gulf of Finland. Hydrobiologia 292/293:249-254

Sherr EB, Sherr BF (1992) Trophic roles of pelaric protists: phagotrophic flagellates as herbivores. Arch 1 fydrobiol Beih Ergebn Limnol 37:165-172

Sherr EB, Sherr BF (1994) Bacteriovory and herbivory: ke: roles of phagotrophic protists in pelagic food webs. Microb Ecol 28:223-235
Sicko-Goard L, Stoemer EF, Ladewski BG (19777) A morphometric method for correcting phytoplankton cell volume estimates. Protoplasma 93:147-163

Sieburth JMcN, Smetacek V, Lentz J (1978) Pelaglc ecosystem structure: heterotrophic compartments and thelr relationship to plankton size fractions. Limnol Oceanogr 23:1256-1263

Smetacek V, Bodungen B von, Knoppers B, Peinert R, Pollehne F, Stegmann P, Zeitzschel B (1984) Seasonal stages in characterizing the annual cycle of an inshore pelagic system. Rapp P.V Réun Cons Int Explor Mer 183 $126-135$

Steemann Nielsen E (1952) The use of radioactive carbon $\left({ }^{14} \mathrm{C}\right)$ for measuring organic production in the sea. J Cons Perm Int Explor Mer 18:117-140

Stoecker DK, Capuzzo JMCD (1990) Predation on protozoa: its importance to zooplankton. J Plankton Res 12:891-908

Stoecker DK, Egloff DA (1987) Predation by Acartia tonsa Dana on planktonic ciliates and rotifers. J Exp Mar Biol Ecol 110:53-68

Strathmann RR (1967) Estimating the organic carbon content of phytoplankton from cell volume or plasma volume. Limnol Oceanogr 12:411-418

Strom, SL (1991) Growth and grazing rates of the herbivorous dinoflagellate Gymnodinium sp. from the open subarctic Pacific Ocean. Mar Ecol Prog Ser 68:121-127

Tamminen T, Kattala S, Kivi K, Kuparinen J (1985) Response of a planktonic brackish water community to single and combined additions of ammonium and of phosphate in a factorial mesocosm experiment. In: Gray JS, Christiansen ME (eds) Marine biology of polar regions and effects of stress on marine organisms. Wiley \& Sons, Chichester, p $363-378$

Taylor AH, Joint I (1990) A steady-state analysis of the 'microbial loop' in stratified systems. Mar Ecol Prog Ser 59:1-17

Tiseluus P (1988) Effects of diurnal feeding rhythms, species composition and vertical migration on the grazing impact of calanoid copepods in the Skagerrak and Kattegat. Ophelia 28:215-230

Tranvik LJ, Sherr EB, Sherr BF (1993) Uptake and utilization of 'colloidal DOM' by heterotrophic flagellates in seawater. Mar Ecol Prog Ser 92:301-309

Turner JT, Roff JC (1993) Trophic levels and trophospecies in marine plankton: lessons from the microbial food web. Mar Microb Food Webs 7:225-248

Uitto A (1996a) Summertime herbivory of the coastal mesozooplankton and metazoan microplankton in the northern Baltic. Mar Ecol Prog Ser 132:47-56

Untto A (1996b) Contribution of nanoprotists to metazooplankton diet in a mesocosm experiment in the coastal northern Baltic. J Plankton Res 18:2119-2137

Uitto A, Kaitala S, Kuosa H, Pajuniemı R (1995) Effect of nutrient addition and predation of mysid shrimp (Neomysis integers on a Baltic plankton community in a short-term enclosure experiment. Aqua I rnn 25:23-3]

Utermöhl $H$ (1958) Zur Vervollkommnung der quantitativen Phytoplankton-Methodik. Mitt Int Verein Theor Angew Limnol 29:117-126

Vistasalo M (1992) Mesozooplankton of the Gulf of Finland and northern Baltic proper - a review of monitoring data. Ophelia 35:147-168

Viitasalo M, Vuorinen I, Saesmaa S (1995) Mesozooplankton dynamics in the northern Baltic Sea connections with hydrography and weather J Plankton Res 17:1857-1878

Voss $M$ (1991) Content of copepod faecal pellets in relation to food supply in Kiel Bight and its effect on sedimentation rãte. Mar Ecol Prog Ser 75:217-225 
Wiadnyana NN, Rassoulzadegan F (1989) Selective feeding of Acartia clausi and Centropages typicus on microzooplankton. Mar Ecol Prog Ser 53:37-45

Wikner J, Hagström $\AA$ (1988) Evidence for tightly coupled nanoplanktonkc predator-prey link regulating the bacteri-

This article was submitted to the editor ovores in the marine environment. Mar Ecol Prog Ser 50: $137-145$

Wikner J, Rassoulzadegan F. Hagström $\AA$ (1990) Periodic bacteriovore activity balances bacterial growth in the marine environment. Limnol Oceanogr 35:313-324

Manuscript first received: August 5, 1996

Revised version accepted: February 18, 1997 